\title{
Expectativas e Incerteza: A Celebração da Química
}

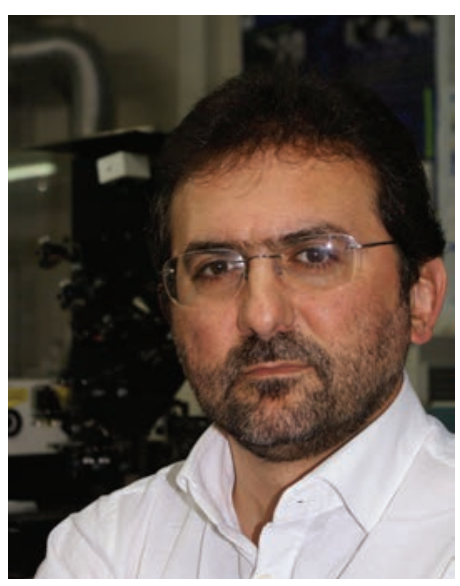

Os dois últimos anos foram de certo modo dedicados à química: 2011 foi o Ano Internacional da Química e, por feliz acaso, foi também o Ano do Centenário da Sociedade Portuguesa de Química, cujas celebrações se estenderam a 2012. A aproximação dessas datas fez-se com enormes expectativas e incertezas, mas sobretudo com muita vontade e enorme excitação. Afinal estava ali a oportunidade de voltar a mostrar ao mundo que não havia mundo sem a química. De tão indispensável e tão intimamente ligada que está ao nosso dia a dia, a maioria das pessoas já nem se apercebe da sua importância. Tudo à nossa volta é química, ou depende da química: esse foi o mote de muito do que se fez nestes dois últimos anos.

Celebrou-se o contributo das mulheres para o desenvolvimento desta ciência, muitas vezes ignorado. Foi também a altura de entusiasmar os jovens e mostrar-lhes que a química é a ciência central cuja importância para sustentação científica e técnica da nossa sociedade é tão óbvia que dispensa justificações. Repito, a química é omnipresente nas nossas necessidades mais elementares, como respirar ou comer. E depois, por ser central, ela faz a ponte com as outras ciências e é também nas interfaces que reside parte da sua atracão, enorme diversidade e riqueza: é na separação incerta com a física que buscamos novas soluções energéticas; é na relação com a biologia que são feitos enormes avanços na área da saúde; é no rigor matemático que encontramos a sistematização necessária para a implementação de novos processos que sustentam o nosso modo de vida. E podia continuar por este caminho, com mais exemplos.

Mas a química também é por si só, e por direito próprio, uma ciência: a ciência da transformação. A síntese de um composto a partir dos reagentes segue um mecanismo característico, com uma cinética exclusiva, com um balanço de massas e energias específico. A síntese de uma molécula simples, como o amoníaco, naquilo que é hoje conhecido como o processo de Bosch-Haber, patenteado em 1910, foi a solução para um mundo em rápido crescimento demográfico que necessitava de ser alimentado. A implicação das descobertas químicas vai quase sempre para além da euforia do momento. Elas constituem a base do desenvolvimento e foram o motor de arranque da revolução industrial e da criação de riqueza pelas nações. A descoberta nem sempre é fruto da necessidade, normalmente ela vem antes, e é a necessidade que deita mão ao portfólio do conhecimento existente.

O Ano Internacional da Química 2011 foi um ano de esforço e incerteza. As expectativas inicialmente geradas foram goradas, fruto da tensão económica que se vivia e que eclodiu na crise atual. A SPQ socorreu-se sobretudo dos seus associados, amigos e investigadores para coordenar um dos programas conjuntos mais ativos de que há memória. Foi o ano em que apesar do empenho anunciado de dezenas de nações, a SPQ viu cortados significativamente os seus apoios nacionais. A todas as empresas, instituições, universidades, escolas e pessoas que acreditaram neste projeto e viveram connosco a permanente insegurança desses dias, mas mesmo assim avançaram, o nosso obrigado. O ano seguinte, 2012, veio confirmar as piores expectativas para a química no panorama nacional. O número de projetos científicos financiados pela FCT foi o mais baixo de sempre e o número de projetos em química e engenharia química catastroficamente exíguo. Percorrendo a lista de projetos aprovados nestas duas áreas, é evidente que foi sobretudo nas interfaces que houve algum sucesso (se é que se pode usar o termo, em face de tão pobre panorama). Ao nível do ensino universitário, houve um decréscimo considerável na procura dos cursos de química e de engenharia química. No ensino secundário, de várias escolas chegaram-nos repetidos pedidos de apoio (de professores e alunos) para justificar a manutenção de pelo menos uma turma de química no $12 .^{\circ}$ ano. Todos sentem que neste ano pré-universitário a disciplina é uma mera opção de catálogo, demasiado fragilizada face à estrutura de avaliação, no desconexo panorama da organização curricular.

Uma nação é seguramente mais do que política e economia. A verdadeira riqueza está no conhecimento; nenhum país possui recursos ilimitados e a história já nos mostrou como os ciclos de prosperidade podem redundar abruptamente na mais profunda das misérias. A formação de indivíduos capazes, por meio de uma educação científica e técnica sólida e sustentada - onde o lugar da química é inquestionável - é a chave do desenvolvimento.

A equipa que agora termina o mandato, e que tive o privilégio de integrar, fez o que estava ao seu alcance, ao serviço da SPQ, ao serviço da química, ao serviço dos químicos portugueses, presentes e futuros. Tenho que agradecer às pessoas que me acompanharam, apoiaram e trabalharam, árdua e desinteressadamente, nesta época desagradável de contratempos e dificuldades. Foram elas que permitiram conduzir este mandato às mãos dos nossos sucessores. Certo é que continuarei a dar o meu contributo, mas a outro nível, pois é tempo de renovar, dar lugar a novas pessoas com novas ideias e novo querer, sabendo de antemão que o seu trabalho não será fácil nas condições adversas que atravessamos. Sem dúvida a nova equipa da SPQ e os seus associados estarão à altura dos acontecimentos. Bem hajam e felicidades.

Joaquim Luís Faria

(jlfaria@fe.up.pt) Secretário Geral da SPQ 